\title{
Pendapatan, Risiko, dan Efisiensi Ekonomi Usahatani Bawang Merah di Kabupaten Bantul
}

D 0 I:10.18196/ agr.2231

\begin{abstract}
This study aims to evaluate the income of shallot farmers, to determine the risk of shallot production, and to examine the level of efficiency of shallot farmers in Bantul Regency. The primary data used in the study was obtained using structured questionnaire administered to 30 selected farmers. R/C ratio, coefficient of variation, and stochastic frontier production function were used to analyze the data. The result showed that shallot farming in Bantul Regency was profitable with incomes of Rp20,903,711/ha. The level of risks faced by farmers were quite high, it was $7.27 \%$. The average level of technical, allocative and economical efficiency of shallot farmers were: 0.802 ; 0.889 ; and 0.929 . This result shows that shallot farmers can increase their technical efficiency and allocative efficiency to
\end{abstract}

achieve an economic efficient condition.

Keywords: efficiency, income, risk, shallot

\section{INTISARI}

Penelitian ini bertujuan untuk menganalisis pendapatan usahatani bawang merah, tingkat risiko usahatani bawang merah, dan tingkat efisiensi usahatani bawang merah di Bantul. Penelitian mengggunakan data primer hasil survei pada 30 petani responden dengan menggunakan kuisioner yang telah dirancang sesuai dengan tujuan penelitian. Data dianalisis menggunakan rasio R/C, koefisien variasi, dan fungsi produksi frontier stokastik. Hasil penelitian menunjukkan bahwa usahatani bawang merah di Kabupaten Bantul menguntungkan dengan pendapatan mencapai Rp20.9 juta per hektar. Tingkat risiko uasaha yang dihadapi petani cukup tinggi, mencapai 7,27\%. Rata-rata tingkat efisiensi teknis, alokatif, dan ekonomi usahatani bawang merah di Kabupaten Bantul masing-masing 0,802; 0,889; dan 0,929. Hasil ini menunjukkan bahwa petani masih dapat meningkatkan efisiensi teknis dan efisiensi alokatif guna mencapai kondisi efisien secara ekonomi.

Kata kunci: bawang merah, efisiensi, pendapatan, risiko

\section{PENDAHULUAN}

Bawang merah merupakan salah satu komoditas sayuran unggulan yang sejak lama telah diusahakan oleh petani secara intensif. Komoditas sayuran ini termasuk ke dalam kelompok rempah tidak bersubstitusi yang berfungsi sebagai bumbu penyedap makanan serta obat tradisonal. Komoditas ini juga merupakan sumber pendapatan dan kesempatan kerja yang memberikan kontribusi cukup tinggi terhadap perkembangan ekonomi wilayah (Balitbang Pertanian, 2005).

Bawang merah dihasilkan hampir di seluruh wilayah Indonesia. Provinsi penghasil utama bawang merah yang ditandai dengan dengan luas areal panen di atas seribu hektar per tahun adalah Sumatera Utara, Sumatera Barat, Jawa 
Barat, Jawa Tengah, Jawa Timur, Nusa Tenggara Barat, Sulawesi Tengah, dan Sulawesi Selatan. Delapan provinsi ini menyumbang 96,8\% dari produksi total bawang merah di Indonesia pada tahun 2013. Sementara itu lima provinsi di Pulau Jawa yang terdiri dari Jawa Barat, Jawa Tengah, Daerah Istimewa Yogyakarta, Jawa Timur, dan Banten memberikan kontribusi sebesar 78,1\% dari produksi total bawang merah nasional. Konsumsi rata-rata bawang merah per kapita untuk tahun 2011-2012 berkisar antara 2,36 kg/ tahun dan 2,74 kg/tahun (Bank Indonesia, 2013).

Produksi bawang merah di Indonesia masih bersifat musiman seperti hasil pertanian pada umumnya. Hal ini menyebabkan kebutuhan bawang merah masyarakat Indonesia di luar musim panen tidak dapat dipenuhi sehingga untuk memenuhinya perlu dilakukan tindakan impor. Pemerintah melakukan impor bawang merah untuk menjaga ketersediaan bawang merah dalam negeri serta kestabilan harga pasar. Tindakan impor ini menjadikan Indonesia menjadi net importir bawang merah. Setiap tahun Indonesia melakukan kegiatan ekspor dan impor bawang merah, tetapi jumlah ekspor tersebut jauh lebih kecil dibandingkan dengan jumlah impor bawang merah ke Indonesia.

Profil usahatani bawang merah dicirikan oleh $80 \%$ petani yang merupakan petani kecil dengan luas lahan kurang dari 1 ha. Berbagai varietas bawang merah yang diusahakan petani antara lain Bima Brebes, Kuning, Bangkok, Bima Sawo, Engkel, Bangkok, Bima Timor, Filipina, dan Thailand (Bank Indonesia, 2013). Usaha budidaya bawang merah ini umumnya merupakan usaha keluarga yang telah dilaksanakan secara turun-temurun. Sebagian besar petani bawang merah sudah melakukan budidaya bawang merah hingga 15-25 tahun. Motivasi pendirian usaha ini di antaranya adalah karena harga jual bawang merah yang cukup baik walaupun dengan pola perubahan yang cukup ekstrem, meneruskan usaha yang telah ada (usaha keluarga), sumber daya alam yang mendukung, dan adanya pengalaman dengan ketrampilan yang sederhana.

Untuk mencapai produktivitas yang maksimal, sistem budidaya bawang merah harus dilakukan secara intensif sehingga perlu keterampilan dan keuletan ekstra dari setiap individu petani. Mengkaji persoalan produktivitas pada dasarnya mengkaji masalah efisiensi usahatani. Hal ini dikarenakan ukuran produktivitas pada hakikatnya mempengaruhi tingkat efisiensi teknis budidaya yang dilakukan oleh petani yang menunjukkan pada seberapa besar output maksimum yang dapat dihasilkan dari tiap input yang tersedia. Tingkat efisiensi akan sangat dipengaruhi oleh kapabilitas manajerial petani dalam aplikasi teknologi budidaya dan pascapanen, serta kemampuan petani dalam mengakumulasikan dan mengolah informasi yang relevan dengan usaha budidayanya sehingga pengambilan keputusan dapat dilakukan dengan tepat.

Dalam menjalankan usahataninya, petani bawang merah menghadapi masalah-masalah yang sifatnya internal maupun eksternal. Masalah internal adalah masalah yang dapat dikontrol oleh petani, sedangkan masalah eksternal adalah masalah yang berada di luar kontrol petani. Permasalahan internal petani antara lain adalah masalah sempitnya penguasaan lahan, rendahnya penguasaan teknologi, serta lemahnya permodalan. Permasalahan eksternal mencakup masalah perubahan iklim, serangan organisme pengganggu tanaman, serta masalah fluktuasi harga jual. Permasalahan tersebut dapat menimbulkan risiko dan ketidakpastian bagi petani (Saptana et. al., 2010)

Besarnya peluang untuk menjangkau pasar nasional maupun pasar internasional menjadikan bawang merah sebagai salah satu komoditi prioritas dalam pengembangan sayuran di Indonesia, yang cukup strategis dan ekonomis dipandang dari segi pendapatan usahatani. Semakin tinggi pendapatan usahatani yang dicapai oleh petani akan menunjukkan keberhasilan petani dalam menjalankan usahataninya secara ekonomi. Untuk itu, pengembangan usahatani bawang merah di Indonesia harus diarahkan untuk mewujudkan agribisnis dan agroindustri yang berdaya saing, berkelanjutan, dan mampu meningkatkan kesejahteraan petani.

Pendapatan usahatani bawang merah menjadi sangat penting untuk diketahui sebagai bahan pertimbangan dalam mengambil keputusan tentang penggunaan teknologi dengan tujuan untuk meningkatkan produksi sekaligus meningkatkan keuntungan ekonomi petani. Setiap petani bawang merah tentu mengharapkan produksi yang tinggi dan sekaligus pendapatan yang memadai. Dalam menghadapi kondisi lingkungan yang serba tidak menentu, seorang petani harus mampu mengalokasikan faktor-faktor produksi yang digunakan sedemikian rupa sehingga usahataninya dapat mencapai tingkat yang efisien dan memperoleh pendapatan yang cukup untuk menghidupi keluarganya dan sekaligus mengembangkan usahataninya.

Berdasarkan uraian diatas, penelitian ini bertujuan untuk menganalisis tingkat pendapatan usahatani bawang merah, tingkat risiko yang dihadapi oleh petani bawang merah, dan tingkat efisiensi usahatani bawang merah di Kabupaten Bantul. 


\section{METODE PENELITIAN}

Penelitian dilakukan di Kabupaten Bantul yang merupakan salah satu sentra produksi bawang merah nasional. Data dikumpulkan dari petani bawang merah di lahan sawah di dari tiga kecamatan dengan rerata produktivitas tertinggi di Kabupaten Bantul, yaitu Kecamatan Sanden, Kretek, dan Srandakan. Sebagai sumber data primer dipilih 30 petani sebagai responden secara purposive, yaitu petani bawang merah di lahan sawah yang menanam padi atau palawija pada musim tanam sebelumnya. Hal ini dimaksudkan agar dapat diketahui biaya pengolahan tanah yang sebenarnya.

Data dianalisis secara kuantitatif menggunakan rumus pendapatan/income untuk mengetahui tingkat pendapatan usahatani bawang merah per musim tanam sebagai berikut.

$\mathrm{I}=\mathrm{TR}-\mathrm{TC}$

$=(\mathrm{Q} \times \mathrm{PQ})-\mathrm{TC}$

di mana:

I : Pendapatan Usahatani Bawang Merah (Rp)

TR : Total Revenue / Penerimaan (Rp)

TC : Total Cost / Biaya Total (Rp)

Q : Produksi $(\mathrm{kg})$

PQ : Harga Jual $(\mathrm{Rp} / \mathrm{kg})$

Untuk mengetahui apakah usahatani bawang merah menguntungkan atau tidak maka digunakan rasio $\mathrm{R} / \mathrm{C}$ sebagai berikut:

\section{Rasio $\mathrm{R} / \mathrm{C}=\frac{\mathrm{TR}}{\mathrm{TC}}$}

di mana:

TR : Total Revenue / Penerimaan ( $\mathrm{Rp})$

TC : Total Cost / Biaya Total (Rp)

Ada tiga kriteria dalam perhitungan Rasio R/C, yaitu :

a. Apabila $\mathrm{R} / \mathrm{C}>1$, maka usahatani menguntungkan layak diusahakan

b. Apabila $\mathrm{R} / \mathrm{C}=1$, maka usahatani berada pada titik impas (break even point)

c. Apabila $\mathrm{R} / \mathrm{C}<1$, maka usahatani tidak menguntungkan atau tidak layak diusahakan

Tingkat risiko usahatani ditentukan berdasarkan nilai koefisien variasi sebagai berikut:

$\mathrm{CV}=\frac{\mathrm{SD}}{\mathrm{E}}$ di mana:

CV : Koefisien Variasi

SD : Standar Deviasi Pendapatan Usahatani

E : Rerata Pendapatan Usahatani

Semakin besar nilai koefisien variasi (CV) maka semakin besar risiko yang harus dihadapi oleh petani bawang merah.

Batas bawah pendapatan (L) juga dihitung untuk menunjukkan nilai nominal pendapatan terendah yang mingkin diterima petani. Apabila nilai kurang dari nol, maka petani kemungkinan besar akan mengalami kerugian. Rumus batas bawah pendapatan adalah sebagai berikut :

$\mathrm{L}=\mathrm{E}-2 \mathrm{~V}$

Keterangan:

L : Batas bawah pendapatan

E : Rerata Pendapatan Usahatani

$\mathrm{V}$ : Simpangan baku

Tingkat efisiensi teknis usahatani bawang merah dianalisis dengan menggunakan fungsi produksi frontier stokastik tipe Cobb-Douglas. Model matematis dari fungsi tersebut dapat dituliskan sebagai berikut.

$\ln \mathrm{Y}=\hat{\mathrm{a}}_{0}+\hat{\mathrm{a}}_{1} \ln \mathrm{X}_{1}+\hat{\mathrm{a}}_{2} \ln \mathrm{X}_{2}+\hat{\mathrm{a}}_{3} \ln \mathrm{X}_{3}+\hat{\mathrm{a}}_{4} \ln \mathrm{X}_{4}+\hat{\mathrm{a}}_{5}$ $\ln X_{5}+\hat{a}_{6} \ln X_{6}+\hat{a}_{7} \ln X_{7}+\hat{a}_{8} \ln X_{8}+\hat{a}_{9} \ln X_{9}+$ $\hat{a}_{10} \ln X_{10}+\hat{a}_{11} \ln X_{11}+(v i-u i)$

Keterangan:

$\mathrm{Y} \quad$ : Produksi bawang merah $(\mathrm{kg})$

$\mathrm{X}_{1} \quad$ : Luas Lahan $\left(\mathrm{m}^{2}\right)$

$\mathrm{X}_{2}$ : Benih $(\mathrm{kg})$

$\mathrm{X}_{3}$ : Pupuk Urea (kg)

$\mathrm{X}_{4}$ : Pupuk ZA (kg)

$\mathrm{X}_{5}$ : Pupuk SP-36 $(\mathrm{kg})$

$\mathrm{X}_{6}$ : Pupuk $\mathrm{KCl}(\mathrm{kg})$

$\mathrm{X}_{7}$ : Pupuk NPK-Phonska (kg)

$\mathrm{X}_{8}$ : Herbisida (ml)

$\mathrm{X}_{9}$ : Fungisida (gr)

$\mathrm{X}_{10}$ : Insektisida (ml)

$\mathrm{X}_{11}$ : Tenaga Kerja (HKO)

$\hat{a}_{0} \quad$ : Intersep

$\hat{a}_{i} \quad$ : Koefisien Regresi

vi : Kesalahan yang dilakukan karena pengambilan secara acak

$\mathrm{u}_{\mathrm{i}}$ : Efek dari in-efisiensi teknis yang muncul

Untuk menentukan nilai efek in-efisiensi pada penelitian ini digunakan persamaan:

$\mathrm{ui}=\ddot{\mathrm{a}}_{0}+\ddot{\mathrm{a}}_{1} \ln \mathrm{Z}_{1}+\ddot{\mathrm{a}}_{2} \ln \mathrm{Z}_{2}+\ddot{\mathrm{a}}_{3} \ln \mathrm{Z}_{3}$

dimana faktor-faktor yang mempengaruhi in-efisiensi teknis meliputi: 
$\ddot{a}_{1}:$ Umur Petani (tahun)

$\ddot{a}_{2}$ : Pendidikan (tahun)

$\ddot{a}_{3}$ : Pengalaman Menjalankan Usahatani Bawang Merah (tahun)

Pendugaan parameter dari persamaan (1) dan (2) dilakukan secara simultan dengan metode Maximum Likelihood Estimation (MLE) menggunakan program FRONTIER 4.1 Coelli (1996). Dengan menggunakan program ini akan didapatkan efisiensi teknis dari usahatani bawang merah, dengan perhitungan:

$$
\mathrm{TE}_{\mathrm{i}}=\frac{\mathrm{Y}}{\mathrm{Y}^{x}}=\frac{\mathrm{E}\left(\mathrm{Y}_{\mathrm{i}} \mid \mathrm{U}_{\mathrm{i}}, \mathrm{X}_{\mathrm{i}}\right)}{\mathrm{E}\left(\mathrm{Y}_{\mathrm{i}} \mid \mathrm{U}_{\mathrm{i}}=0, \mathrm{X}_{\mathrm{i}}\right)}=\mathrm{E}\left[\exp \left(-\mathrm{U}_{\mathrm{i}}\right) / \varepsilon_{\mathrm{i}}\right]
$$

Keterangan:

$\mathrm{TE}_{\mathrm{i}}$ : Efisiensi Teknis Petani ke i

Y : Produksi Aktual

$\mathrm{Y}^{*} \quad$ : Produksi Potensial (diperoleh dari fungsi produksi frontier stokastik)

dimana nilai $\mathrm{TE}_{\mathrm{i}}$ berkisar antara 0 dan 1.

Jika nilai TE semakin mendekati 1 (satu) maka usahatani bawang merah dapat dikatakan semakin efisien secara teknis dan jika semakin mendekati $\mathrm{O}$ (nol) maka usahatani bawang merah dapat dikatakan in-efisien secara teknis. Suatu metode produksi dapat dikatakan lebih efisien dari metode lainnya jika metode tersebut menghasilkan output yang lebih besar pada tingkat korbanan yang sama. Suatu metode produksi yang menggunakan korbanan yang paling kecil, juga dikatakan lebih efisien dari metode produksi lainnya jika menghasilkan output yang sama besarnya. Mubyarto (1982) menyatakan bahwa efisiensi dalam usahatani merupakan salah satu indikator keberhasilan proses produksi.

Efisiensi ekonomi akan tercapai apabila efisiensi teknis dan efisiensi alokatif dapat dicapai. Perbedaan tingkat efisiensi ekonomi antara usahatani satu dengan usahatani yang lain disebabkan oleh perbedaan tingkat efisiensi teknis atau efisiensi alokatif atau keduanya. Efisiensi ekonomi merupakan hasil kali antara seluruh efisiensi teknis dengan efisiensi alokatif dari seluruh faktor produksi.

Menurut Jondrow et. al. (1982) dalam Ogundari dan Ojo (2007), efisiensi ekonomi (Economic Efficiency/EE) didefinisikan sebagai rasio antara biaya total produksi minimum yang diobservasi $\left(\mathrm{C}^{*}\right)$ dengan biaya total aktual (C), sebagaimana dirumuskan pada persamaan berikut :

$$
\mathrm{EE}=\frac{c^{*}}{C}=\frac{E\left(C_{i} \mid U_{i}=0, Y_{i} P_{i}\right)}{E\left(C_{i} \mid U_{i}, Y_{i}, X_{i}\right)}=\mathrm{E}\left[\exp \left(-U_{i}\right) / \varepsilon_{i}\right]
$$

Keterangan :
EE : Efisiensi Ekonomi (Economic Efficiency)

$\mathrm{C}^{*} \quad$ : Total Biaya Produksi Minimum

C : Total Biaya Produksi Aktual

dimana nilai EE berkisar antara 0 dan 1 .

Dalam penelitian ini, analisis efisiensi ekonomi dilakukan dengan menggunakan model fungsi biaya frontier stokastik tipe Cobb-Douglas sebagai berikut.

$\ln \mathrm{C}=\hat{\mathrm{a}}_{0}+\hat{a}_{1} \ln \mathrm{Y}+\hat{\mathrm{a}}_{2} \ln \mathrm{P}_{2}+\hat{\mathrm{a}}_{3} \ln \mathrm{P}_{3}+\hat{\mathrm{a}}_{4} \ln \mathrm{P}_{4}+\hat{\mathrm{a}}_{5} \ln$ $\mathrm{P}_{5}+\hat{\mathrm{a}}_{6} \ln \mathrm{P}_{6}+\hat{\mathrm{a}}_{7} \ln \mathrm{P}_{7}+\hat{\mathrm{a}}_{8} \ln \mathrm{P}_{8}+\hat{\mathrm{a}}_{9} \ln \mathrm{P}_{9}+\hat{\mathrm{a}}_{10} \ln$ $\mathrm{P}_{10}+\hat{a}_{11} \ln \mathrm{P}_{11}+(\mathrm{vi}-\mathrm{ui})$

Keterangan :

C : Total Biaya Produksi (Rp)

$\mathrm{Y}$ : Produksi bawang merah $(\mathrm{kg})$

$\mathrm{P}_{2} \quad$ : Harga Benih $(\mathrm{Rp} / \mathrm{kg})$

$\mathrm{P}_{3} \quad$ : Harga Pupuk Urea $(\mathrm{Rp} / \mathrm{kg})$

$\mathrm{P}_{4} \quad$ : Harga Pupuk ZA $(\mathrm{Rp} / \mathrm{kg})$

$\mathrm{P}_{5} \quad$ : Harga Pupuk SP-36 $(\mathrm{Rp} / \mathrm{kg})$

$\mathrm{P}_{6} \quad$ : Harga Pupuk KCl $(\mathrm{Rp} / \mathrm{kg})$

$\mathrm{P}_{7} \quad$ : Harga Pupuk NPK-Phonska $(\mathrm{Rp} / \mathrm{kg})$

$\mathrm{P}_{8} \quad$ : Harga Hebisida $(\mathrm{Rp} / \mathrm{ml})$

$\mathrm{P}_{9} \quad$ : Harga Fungisida $(\mathrm{Rp} / \mathrm{gr})$

$\mathrm{P}_{10}$ : Harga Insektisida $(\mathrm{Rp} / \mathrm{ml})$

$\mathrm{P}_{11}$ : Upah Tenaga Kerja $(\mathrm{Rp} / \mathrm{HKO})$

$\hat{\mathrm{a}}_{0} \quad$ : Intersep

$\hat{a}_{i} \quad$ : Koefisien Regresi

$\mathrm{v}_{\mathrm{i}} \quad$ : Kesalahan yang dilakukan karena pengambilan secara acak

$\mathrm{u}_{\mathrm{i}} \quad$ : Efek dari inefisiensi teknis yang muncul

Untuk menentukan efek in-efisiensi digunakan persamaan:

$\mathrm{ui}=\ddot{a}_{0}+\ddot{a}_{1} \ln Z_{1}+\ddot{a}_{2} \ln Z_{2}+\ddot{a}_{3} \ln Z_{3}$

dimana faktor-faktor yang mempengaruhi in-efisiensi meliputi:

$\mathrm{Z}_{1} \quad$ : Umur Petani (tahun)

$\mathrm{Z}_{2} \quad$ : Pendidikan (tahun)

$Z_{3}$ : Pengalaman Menjalankan Usahatani Bawang Merah (tahun)

Sama seperti pada analisis sebelumya, pendugaan parameter dari persamaan (3) dan (4) dengan metode Maximum Likelihood Estimation (MLE) dilakukan secara simultan menggunakan program software FRONTIER 4.1 Coelli (1996).

Namun, perlu diingat perhitungan program komputasi tersebut mengukur efisiensi biaya (Cost Efficiency/CE), sebagaimana diacu dari Coelli (1996) dalam Ogundari dan 
Ojo (2007). Oleh karena itu tingkat efisiensi ekonomi (Economic Efficiency/EE) usahatani bawang merah diperoleh dengan menggunakan rumus:

$$
E E=\frac{1}{\text { Cost Efficiency }(C E)}
$$

Efisiensi ekonomi (EE) merupakan hasil kali dari efisiensi teknis (TE) dan efisiensi alokatif (EA). Oleh karena itu nilai efisiensi alokatif (EA) dapat diperoleh dengan persamaan:

$$
\mathrm{EA}=\frac{\mathrm{EE}}{\mathrm{ET}}
$$

dengan nilai $\mathrm{AE}$ berkisar antara 0 dan 1 .

\section{HASIL DAN PEMBAHASAN}

\section{PENGGUNAAN SARANA PRODUKSI}

Benih merupakan faktor produksi yang sangat penting dalam usahatani bawang merah. Penggunaan benih unggul akan mampu memberikan hasil produksi yang lebih baik dibandingkan dengan benih yang tidak unggul. Penggunaan benih unggul untuk usahatani bawang merah tidak hanya diarahkan untuk peningkatan kuantitas hasil produksi, tetapi juga diarahkan untuk peningkatan kualitas/mutu dari produksi yang dihasilkan.

TABEL I. RERATA PENGGUNAAN PUPUK UNTUK USAHATANI BAWANG MERAH

\begin{tabular}{lll}
\hline Jenis Pupuk (kg/ha) & $\mathbf{n}$ & Rerata \\
\hline Urea & 18 & 153,93 \\
ZA & 14 & 282,69 \\
SP-36 & 20 & 380,07 \\
KCl & 21 & 188,67 \\
NPK Phonska & 25 & 400,92 \\
NPK Mutiara & 12 & 244,14 \\
DAP & 9 & 150,04 \\
Petroganik & 5 & $1.531,23$ \\
Kandang & 11 & $5.546,79$ \\
\hline
\end{tabular}

Terdapat dua jenis varietas bawang merah yang dominan ditanam di Kabupaten Bantul, yaitu biru dan tiron. Kedua varietas tersebut banyak dipilih petani karena memiliki potensi hasil yang tinggi dan tahan terhadap hama dan penyakit. Varietas biru paling disukai petani, karena berumur pendek, berumbi besar, dan memiliki harga jual yang relatif tinggi. Sementara varietas tiron disukai petani karena tahan terhadap hujan, berwarna merah cerah, dan memiliki daya tahan simpan yang lama, walaupun varietas ini berumbi kecil dan berumur panjang. Rata-rata penggunaan benih bawang merah di Kabupaten Bantul sekitar 878 kg kg/ha.

Faktor produksi pupuk adalah bahan yang mengandung satu atau lebih unsur hara yang ditambahkan pada tanaman, baik secara langsung maupun tidak langsung. Jenis-jenis pupuk yang digunakan beserta rerata penggunaannya untuk usahatani bawang merah dapat dilihat pada Tabel 1.

Penggunaan pupuk merupakan usaha petani untuk meningkatkan produktivitas lahan, yaitu dengan cara menambah unsur hara yang diperlukan tanaman. Pemupukan sangat penting untuk meningkatkan produksi tanaman, yaitu dengan menambah ketersediaan unsur hara dalam tanah. Dengan demikian diharapkan kebutuhan tanaman akan unsur hara akan dapat terpenuhi secara optimal. Tabel 1 menunjukkan bahwa petani bawang merah di Kabupaten Bantul cukup intensif dalam perlakuan pemupukan pada tanaman bawang merah, terutama pada pemberian pupuk majemuk yang mengandung unsur hara esensial yang dibutuhkan oleh tanaman seperti nitrogen $(\mathrm{N})$, fosfor $(\mathrm{P})$, dan kalium $(\mathrm{K})$, di antaranya adalah NPK Phonska dan NPK Mutiara. Selain itu, separuh petani bawang merah di Kabupaten Bantul menggunakan pupuk organik, baik berupa pupuk kandang maupun petroganik, pada lahan bawang merah mereka.

Faktor produksi pestisida adalah bahan yang digunakan untuk mengendalikan organisme pengganggu tanaman. Jenis-jenis pestisida yang digunakan oleh petani bawang merah antara lain herbisida, fungisida, dan insektisida. Rerata penggunaan pestisida untuk usahatani bawang merah dapat dilihat pada Tabel 2.

TABEL 2. RERATA PENGGUNAAN PESTISIDA UNTUK USAHATANI BAWANG MERAH

\begin{tabular}{lll}
\hline Jenis Pestisida & n & Rerata \\
\hline Herbisida (m//ha) & 30 & 1.140 \\
Fungisida Padat (gr/ha) & 25 & 5.962 \\
Fungisida Cair (ml/ha) & 24 & 1.123 \\
Insektisida Padat (gr/ha) & 2 & 857 \\
Insektisida Cair (m//ha) & 25 & 1.511 \\
\hline
\end{tabular}

Secara umum usahatani bawang merah merupakan jenis usahatani yang membutuhkan banyak asupan pestisida. Pemberian pestisida dimaksudkan untuk mengendalikan organisme pengganggu tanaman, seperti hama, patogen penyebab penyakit tanaman, dan gulma. Tabel 2 
menunjukkan bahwa petani bawang merah di Kabupaten Bantul menggunakan berbagai jenis pestisida dengan cukup intensif.

Tenaga kerja merupakan salah satu faktor produksi utama dalam usahatani bawang merah. Dalam mengelola usahataninya, petani tidak hanya menyumbangkan tenaganya, tetapi juga kemampuan dan keahlian yang dimilikinya. Rerata penggunaan tenaga kerja untuk usahatani bawang merah dapat dilihat pada Tabel 3 .

tABEL 3. RERATA CURAhAN teNAGA KERJA UNTUK USAHATANI BAWANG MERAH

\begin{tabular}{lll}
\hline $\begin{array}{l}\text { Curahan Tenaga Kerja } \\
\text { (HKO/ha) }\end{array}$ & Laki-Laki & Wanita \\
\hline Persiapan Benih dan Lahan & 58,01 & 14,38 \\
Tanam dan Pemeliharaan & 447,67 & 6,90 \\
Panen & 47,89 & 1,35 \\
\hline Total & 553,56 & 22,64 \\
\hline
\end{tabular}

Usahatani bawang merah merupakan tipe usahatani yang membutuhkan banyak curahan tenaga kerja. Secara umum, curahan tenaga kerja tersebut dapat dibedakan dalam tiga jenis pekerjaan, yaitu: i) persiapan benih dan lahan, ii) tanam dan pemeliharaan, serta iii) panen. Jenis pekerjaan yang pertama meliputi pembelahan benih, pembuatan selokan, pelembutan tanah, pembuatan garis tanam, pemberian herbisida pra-tanam, dan pemberian pupuk dasar. Jenis pekerjaan yang kedua mencakup penanaman, pemupukan, penyemprotan pestisida, penyiraman, dan penyiangan. Sementara jenis pekerjaan yang ketiga meliputi panen dan pengangkutan hasil panen.

Tabel 3 menunjukkan bahwa penggunaan tenaga kerja petani di Kabupaten Bantul cukup intensif. Hal ini terlihat jelas terutama untuk jenis pekerjaan yang kedua, yaitu penanaman dan pemeliharaan. Keadaan ini dapat dimengerti mengingat kondisi tanah di Kabupaten Bantul yang memerlukan perhatian dan penanganan lebih seperti pemupukan, penyemprotan pestisida, dan penyiraman yang cukup intensif. Akibatnya, curahan tenaga kerja yang dikeluarkan oleh petani menjadi lebih banyak.

\section{PRODUKSI BAWANG MERAH}

Tinggi rendahnya produksi dan produktivitas bawang merah sangat dipengaruhi oleh modal yang tersedia dan teknik budidaya yang dilakukan oleh petani. Produksi dan produktivitas usahatani selanjutnya dapat digunakan untuk mengetahui apakah suatu usahatani telah dikelola dengan baik atau tidak. Rata-rata produksi usahatani bawang merah di Kabupaten Bantul mencapai 12,24 ton/ha (Tabel 4).

TABEL 4. RERATA PENGUASAAN LAHAN, JUMLAH BENIH, DAN PRODUKTIVITAS BAWANG MERAH

\begin{tabular}{ll}
\hline Uraian & Rerata \\
\hline Luas Lahan (ha) & 0,25 \\
Jumlah Benih (kg/ha) & 878,48 \\
Produksi (kg) & $3.026,67$ \\
Produktivitas (kg/ha) & $12.243,69$ \\
Produktivitas (ton/ha) & 12,24 \\
\hline
\end{tabular}

Berdasarkan Tabel 4 dapat diketahui bahwa rerata produksi bawang merah petani di Kabupaten Bantul sebesar $3.026,67 \mathrm{~kg}$ per usahatani, dengan produktivitas $12,24 \mathrm{ton} /$ ha. Nilai ini lebih tinggi dari rerata produktivitas nasional selama rentang 2007-2013 yaitu sebesar 9,46 ton/ha. Produktivitas yang cukup tinggi ini dapat dicapai oleh petani di Kabupaten Bantul disebabkan oleh beberapa faktor di antaranya adalah penggunaan varietas, pola tanam, dan waktu tanam.

\section{NILAI PRODUKSI DAN STRUKTUR BIAYA USAHATANI BAWANG MERAH}

Salah satu indikator penting dalam penilaian ekonomi usahatani adalah dengan melihat nilai produksi yang diperoleh petani. Nilai produksi atau penerimaan usahatani merupakan perkalian antara jumlah produksi dengan harga yang diterima oleh petani. Nilai produksi usahatani bawang merah di Kabupaten Bantul dapat dilihat pada Tabel 5.

Berdasarkan Tabel 5 dapat diketahui bahwa penerimaan usahatani bawang merah di Kabupaten Bantul mencapai Rp67.132.814,00/ha. Besarnya penerimaan ini dipengaruhi oleh jumlah produksi dan harga yang diterima oleh petani bawang merah. Walaupun produksi yang dihasilkan petani tinggi, seringkali harga yang diterima petani rendah sehingga besarnya penerimaan usahatani tidak maksimal.

Tabel 5 juga menunjukkan bahwa biaya total usahatani bawang merah adalah sebesar Rp46.229.103,00/ha. Dilihat dari struktur biaya usahatani, tenaga kerja menjadi pos biaya yang paling tinggi karena mencakup 46,94\% dari total biaya yang harus dikeluarkan oleh petani di Kabupaten Bantul. Hal ini menunjukkan usahatani bawang merah adalah tipe usahatani yang cukup intensif dalam penggunaan tenaga kerja. Biaya benih menjadi pos biaya terbesar kedua setelah 
tenaga kerja. Sementara itu, biaya pupuk dan pestisida hanya mencakup sekitar 4 - 9\% dari total biaya usahatani bawang merah.

TABEL 5. NILAI PRODUKSI DAN STRURTUR BIAYA USAHATANI BAWANG MERAH

\begin{tabular}{lll}
\hline \multirow{2}{*}{ Uraian } & \multicolumn{2}{l}{ Kab. Bantul } \\
\cline { 2 - 3 } & Jumlah & Persentase (\%) \\
\hline Penerimaan & & \\
Produksi (kg/ha) & 12.244 & \\
Harga (Rp) & 5.492 & \\
Nilai Produksi (Rp/ha) & 67.132 .814 & \\
Biaya Variabel (NaiaddeCost) & & \\
Benih (Rp/ha) & 12.907 .927 & 27,92 \\
Pupuk (Rp/ha) & 4.079 .884 & 8,83 \\
Pestisida (Rp/ha) & 2.080 .691 & 4,50 \\
Tenaga Kerja (Rp/ha) & 21.699 .674 & 46,94 \\
Biaya Tetap (FixedCos) & & \\
Sewa Lahan (Rp/ha/musim) & 5.111 .508 & 11,06 \\
Penyusutan & 349.419 & 0,76 \\
Biaya Total (Rp/ha) & 46.229 .103 & 100,00 \\
\hline
\end{tabular}

\section{PENDAPATAN USAHATANI BAWANG MERAH}

Nilai produksi setelah dikurangi dengan biaya-biaya yang telah dikeluarkan akan didapatkan nilai pendapatan usahatani. Semakin tinggi pendapatan yang diterima oleh petani, maka usahataninya dapat dikatakan lebih berhasil secara ekonomi. Pendapatan inilah yang kemudian akan digunakan oleh petani untuk memenuhi kebutuhan hidupnya.

TABEL 6. PENDAPATAN USAHATANI BAWANG MERAH DI KABUPATEN BANTUL

\begin{tabular}{ll}
\hline Uraian & Jumlah (Rp/ha) \\
\hline Penerimaan (R) & 67.132 .814 \\
Biaya Variabel & 40.768 .176 \\
Biaya Tetap & 5.460 .927 \\
Total Biaya (C) & 46.229 .103 \\
Pendapatan & 20.903 .711 \\
R/C & 1,45 \\
\hline
\end{tabular}

Tabel 6 menunjukkan bahwa pendapatan yang diterima oleh petani bawang merah di Kabupaten Bantul adalah sebesar Rp20.903.711/ha dengan nilai R/C sebesar 1,45. Hasil ini menunjukkan bahwa usahatani bawang merah di Kabupaten Bantul secara ekonomi menguntungkan dan layak untuk diusahakan.

TABEL 7. USAHATANI BAWANG MERAH DI KABUPATEN BANTUL

\begin{tabular}{ll}
\hline Uraian & Pendapatan \\
\hline Rerata (Rp/ha) & 20.903 .711 \\
Standar Deviasi & 15.192 .314 \\
Koefisien Variasi & 0,727 \\
Batas Bawah Pendapatan $(L)$ & -9.480 .916 \\
\hline
\end{tabular}

\section{RISIKO USAHATANI BAWANG MERAH}

Analisis koefisien variasi dari pendapatan usahatani bawang merah digunakan untuk mengetahui risiko pendapatan usahatani bawang merah. Semakin kecil nilai koefisien variasi maka semakin kecil risiko yang dihadapi petani. Sebaliknya semakin besar koefisien variasi maka semakin besar pula risiko yang dihadapi oleh petani.

Tabel 7 menunjukkan bahwa usahatani bawang merah di Kabupaten Bantul menghadapi risiko pendapatan sebesar 0,727 atau $72,7 \%$. Artinya untuk setiap satu rupiah dari pendapatan yang diterima oleh petani, maka risiko yang dihadapi adalah sebesar 0,727 rupiah. Batas bawah pendapatan (L) yang dihasilkan usahatani bawang merah adalah sebesar Rp-9.480.916. Nilai L < 0 menunjukkan bahwa usahatani bawang merah di Kabupaten Bantul memberikan kemungkinan mengalami kerugian pada setiap proses produksinya. Angka tersebut menunjukkan bahwa petani bawang merah harus berani menanggung kerugian sebesar Rp9.480.916 pada setiap proses produksi.

\section{EFISIENSI TEKNIS, ALOKATIF, DAN EKONOMI USAHATANI BAWANG MERAH}

Berikut ini adalah hasil estimasi fungsi produksi stokastik frontier dengan menggunakan pendekatan Maximum Likelihood Estimation (MLE), sebagaimana ditampilkan pada Tabel 8. Metode MLE ini menggambarkan kinerja terbaik (best practice) dari perilaku petani dalam proses produksi. Fungsi produksi frontier ini akan digunakan untuk mengetahui faktor-faktor yang mempengaruhi produksi bawang merah dan juga sebagai dasar untuk menghitung 
TABEL 8. ESTIMASI FUNGSI PRODUKSI FRONTIER STOKASTIK USAHATANI BAWANG MERAH

\begin{tabular}{lllll}
\hline Variabel & Parameter & Koefisien & & T-ratio \\
\hline Konstanta & $\beta_{0}$ & 0,37744 & ns & 0,43289 \\
Luas Lahan & $\beta_{1}$ & 0,66579 & $* * *$ & 10,12172 \\
Benih & $\beta_{2}$ & $-0,17112$ & ns & $-0,93594$ \\
Pupuk Urea & $\beta_{3}$ & 0,00665 & ns & 0,72494 \\
Pupuk ZA & $\beta_{4}$ & $-0,00079$ & ns & $-0,07019$ \\
Pupuk SP-36 & $\beta_{5}$ & 0,01862 & $* *$ & 2,35378 \\
Pupuk KCl & $\beta_{6}$ & 0,00259 & ns & 0,23901 \\
Pupuk NPK-Phonska & $\beta_{7}$ & 0,02641 & $* * *$ & 3,05581 \\
Herbisida & $\beta_{8}$ & 0,04565 & ns & 0,49650 \\
Fungisida & $\beta_{9}$ & 0,05082 & $* *$ & 2,48934 \\
Insektisida & $\beta_{10}$ & 0,11763 & ns & 1,45325 \\
Tenaga Kerja & $\beta_{11}$ & 0,51298 & $* *$ & 2,74632 \\
Sigma-squared & & 0,09427 & $* *$ & 2,0787 \\
Gamma & & 0,99997 & $* * *$ & $4.911,5$ \\
\hline
\end{tabular}

Keterangan: $* * * \quad$ : signifikan pada á $=1 \%$

** $\quad$ : signifikan pada á $=5 \%$

* $\quad$ : signifikan pada á $=10 \%$

ns : non-signifikan

efisiensi produksi usahatani bawang merah.

Hasil estimasi menunjukkan nilai sigma-squared sebesar 0,09427 dan signifikan pada á sebesar 5\%, sehingga dapat dimaknai bahwa keragaman produksi bawang merah di Kabupeten Bantul yang disumbangkan oleh efek in-efisiensi dan efek eksternal mempunyai variasi yang nyata. Kemudian nilai gamma didapatkan sebesar 0,99997 dan signifikan pada á sebesar $1 \%$. Hal ini menunjukkan bahwa $99,9 \%$ tingkat variasi produksi bawang merah di Kabupaten Bantul disebabkan oleh perbedaan efisiensi teknis dan sisanya sebesar $0,1 \%$ disebabkan oleh pengaruh eksternal seperti iklim, serangan hama dan penyakit, dan kesalahan dalam pemodelan. Hal ini menunjukkan bahwa pengaruh inefisiensi teknis merupakan faktor yang berpengaruh nyata dalam variabilitas produksi bawang merah.

Seluruh variabel faktor-faktor produksi yang dimasukkan dalam model bertanda positif, kecuali faktor produksi benih dan pupuk ZA. Koefisien yang bertanda positif dari faktor produksi luas lahan, pupuk Urea, pupuk SP-36, pupuk KCl, pupuk NPK-Phonska, herbisida, fungisida, insektisida, dan tenaga kerja menunjukkan bahwa penambahan masingmasing faktor produksi tersebut akan dapat meningkatkan produksi bawang merah. Sementara itu, koefisien yang bertanda negatif dari faktor produksi benih menunjukkan bahwa penambahan jumlah benih tidak meningkatkan produksi bawang merah namun justru sebaliknya dapat menurunkan jumlah output. Hal ini disebabkan karena penggunaan benih yang berlebihan oleh petani. Penggunaan benih yang berlebihan ini akan menyebabkan jarak tanam terlalu rapat sehingga tanaman tidak dapat tumbuh dan berkembang secara optimal. Selain itu, penambahan jumlah pupuk ZA juga tidak meningkatkan produksi bawang.

Pengujian secara parsial pada fungsi produksi, sebagaimana ditampilkan pada Tabel 8 , menunjukkan bahwa faktor produksi luas lahan, pupuk SP-36, pupuk NPKPhonska, fungisida, dan tenaga kerja berpengaruh nyata terhadap produksi bawang merah. Sementara faktor produksi benih, pupuk Urea, pupuk ZA, pupuk KCl, herbisida, dan insektisida tidak berpengaruh nyata terhadap produksi bawang merah.

Secara umum, karakteristik model produksi frontier untuk menduga efisiensi teknis adalah adanya pemisahan dampak dari goncangan peubah eksogen terhadap keluaran melalui kontribusi ragam yang menggambarkan efisiensi teknis (Giannakas et. al., 2003 dalam Sukiyono, 2005). Dengan kata lain, penggunaan metode ini dimungkinkan untuk 
menduga ketidakefisienan suatu proses produksi tanpa mengabaikan error term dari modelnya. Selain itu, pendugaan efisiensi menggunakan fungsi produksi frontier memungkinkan untuk dapat diketahui tingkat efisiensi yang dicapai oleh tiap individu unit-unit usahatani (Coelli et al., 1998), sebagaimana ditampilkan pada Tabel 9.

TABEL 9. DISTRIBUSI EFIIIENSI TEKNIS (ET) USAHATANI BAWANG MERAH DI KABUPATEN BANTUL

\begin{tabular}{lll}
\hline Tingkat Efisiensi Teknis & Jumlah Petani & Persentase \\
\hline$<0,5$ & 4 & 13,33 \\
$0,51-0,60$ & 2 & 6,67 \\
$0,61-0,70 \quad 2$ & & 6,67 \\
$0,71-0,80$ & 4 & 13,33 \\
$0,81-0,90$ & 6 & 20,00 \\
$0,91-1,00$ & 12 & 40,00 \\
\hline Jumlah & 30 & \\
Rerata & 0,802 & \\
Nilai Minimum & 0,289 & \\
Nilai Maksimum & 0,997 & \\
\hline
\end{tabular}

TABEL I0. ESTIMASI FAKTOR-FAKTOR YANG MEMPENGARUHI IN-EFISIENSI TEKNIS USAHATANI BAWANG MERAH DI KABUPATEN BANTUL

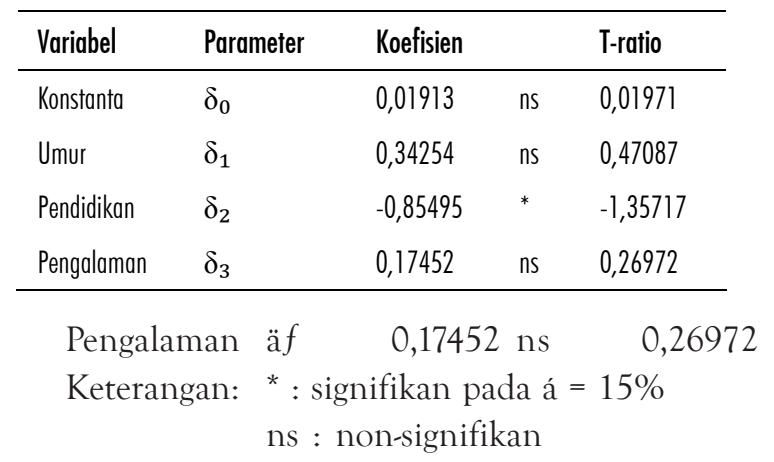

Hasil analisis menunjukkan tingkat efisiensi teknis yang dicapai oleh petani bawang merah di Kabupaten Bantul berkisar antara 0,289 hingga 0,999 dengan rata-rata 0,802. Dari 30 petani terdapat 18 petani $(60,00 \%)$ yang telah mencapai tingkat efisiensi diatas 0,800 atau $80 \%$. Hal ini menandakan bahwa masih terdapat $40 \%$ petani bawang merah yang masih berada pada tingkat efisiensi teknis dibawah $80 \%$ atau masih mengalami in-efisiensi teknis dalam usahataninya. Tidak dapat dipungkiri bahwa terdapat perbedaan tingkat efisiensi teknis yang mampu dicapai oleh masing-masing individu petani. Hal ini menunjukkan bahwa masih ada ruang dari petani bawang merah untuk meningkatkan efisiensi teknis melalui peningkatan manajemen usahatani

Perbedaan tingkat efisiensi teknis yang dicapai petani bawang merah mengindikasikan tingkat penguasaan dan aplikasi teknologi yang berbeda-beda. Perbedaan tingkat pengusaan teknologi disebabkan oleh atribut yang melekat pada diri petani seperti umur, pendidikan, dan pengalaman berusahatani serta dapat juga disebabkan oleh faktor eksternal seperti penyuluhan. Perbedaan dalam aplikasi teknologi maksudnya adalah perbedaan dalam hal pengalokasian input produksi. Disamping itu, tingkat efisiensi teknis yang berbeda-beda juga disebabkan oleh kemampuan petani untuk mendapatkan input produksi. Jumlah anggota keluarga usia produktif juga berperan dalam hal penggunaan input tenaga kerja (Fadwiwati et. al., 2014).

TABEL II. ESTIMASI FUNGSI BIAYA FRONTIER STOKASTIK USAHATANI BAWANG MERAH

\begin{tabular}{|c|c|c|c|c|}
\hline Variabel & Parameter & Koefisien & & T-ratio \\
\hline Konstanta & $\beta_{0}$ & 9,05824 & $* *$ & 2,65754 \\
\hline Produksi Bawang Merah & $\beta_{1}$ & 0,46105 & * & 1,92370 \\
\hline Harga Benih & $\beta_{2}$ & 0,28535 & $* * *$ & 2,87228 \\
\hline Harga Pupuk Urea & $\beta_{3}$ & 0,13842 & $* * *$ & 3,92997 \\
\hline Harga Pupuk ZA & $\beta_{4}$ & 0,14661 & $* * *$ & 5,43294 \\
\hline Harga Pupuk SP-36 & $\beta_{5}$ & 1,60591 & ${ }^{* * *}$ & 4,03542 \\
\hline Harga Pupuk KCl & $\beta_{6}$ & 0,15687 & $*$ & 1,74437 \\
\hline Harga Pupuk NPK-Phonska & $\beta_{7}$ & 0,35499 & * & 1,93500 \\
\hline Harga Herbisida & $\beta_{8}$ & $-0,26287$ & ns & $-0,67834$ \\
\hline Harga Fungisida & $\beta_{9}$ & $-0,62239$ & ns & $-0,57674$ \\
\hline Harga Insektisida & $\beta_{10}$ & 0,13760 & ** & 2,09406 \\
\hline Upah Tenaga Kerja & $\beta_{11}$ & 0,88585 & ** & 2,53896 \\
\hline Konstanta & $\delta_{0}$ & 2,36686 & ** & 2,23898 \\
\hline Umur Petani & $\delta_{1}$ & $-0,14414$ & $* * *$ & $-6,00296$ \\
\hline Pendidikan Petani & $\delta_{2}$ & $-0,12447$ & ns & $-0,63776$ \\
\hline Pengalaman Petani & $\delta_{3}$ & 0,11212 & ns & 0,65211 \\
\hline Sigma-squared & & 0,10143 & $* * *$ & 5,22460 \\
\hline Gamma & & 0,99999 & $* * *$ & $79.496,1$ \\
\hline
\end{tabular}

\begin{tabular}{ll}
\hline Mean Efficiency $\quad 1,132$ \\
\hline
\end{tabular}

$\begin{array}{lll}\text { Sigma-squared } & 0,10143 * * * & 5,22460 \\ \text { Gamma } & 0,99999^{* * *} & 79.496,1 \\ \text { Mean Efficiency } & 1,132 & \\ \text { Keterangan: } * * * & \text { : signifikan pada á }=1 \%\end{array}$




$$
\begin{array}{ll}
* * & : \text { signifikan pada á }=5 \% \\
* & : \text { signifikan pada á }=10 \% \\
\text { ns } & : \text { non-signifikan }
\end{array}
$$

Faktor-faktor yang diduga mempengaruhi in-efisiensi teknis usahatani bawang merah di Kabupaten Bantul adalah umur, pendidikan, dan pengalaman petani. Hasil estimasi pada Tabel 10 menunjukkan bahwa hanya pendidikan yang berpengaruh nyata terhadap in-efisiensi usahatani bawang merah pada tingkat á sebesar 15\%. Tingkat pendidikan memiliki koefisien bertanda negatif yang dapat dimaknai bahwa semakin tinggi tingkat pendidikan petani, maka semakin kecil petani tersebut melakukan ketidakefisienan dalam menjalankan usahatani bawang merah. Atau dengan kata lain, semakin tinggi tingkat pendidikan petani maka petani tersebut akan semakin efisien dalam menjalankan usahataninya.

Selanjutnya efisiensi ekonomi usahatani bawang merah diestimasi dengan menggunakan fungsi biaya stokastik frontier dengan metode Maximum Likelihood Estimation (MLE). Kemudian nilai efisiensi alokatif diprediksi dengan membagi nilai efisiensi ekonomi dengan efisiensi teknis sebagaimana telah ditampilkan pada persamaan 6. Hasil estimasi fungsi biaya stokastik frontier ditampilkan dalam Tabel 11 berikut ini.

Hasil estimasi menunjukkan bahwa terdapat sembilan variabel yang berpengaruh nyata terhadap biaya produksi usahatani bawang merah, yaitu jumlah produksi bawang merah, harga benih, harga pupuk Urea, harga pupuk ZA, harga pupuk SP-36, harga pupuk $\mathrm{KCl}$, harga pupuk NPKPhonska, harga insektisida, dan upah tenaga kerja. Kesembilan variabel tersebut masing-masing memberikan pengaruh positif terhadap biaya produksi bawang merah. Selain itu, hasil estimasi juga menunjukkan variabel umur petani berpengaruh nyata terhadap in-efisiensi biaya pada tingkat á sebesar $1 \%$. Umur petani memiliki koefisien bertanda negatif yang dapat dimaknai bahwa semakin tua umur petani, maka semakin kecil petani tersebut melakukan ketidakefisienan dalam menjalankan usahatani bawang merah. Atau dengan kata lain, semakin tua umur petani maka petani tersebut akan semakin efisien dalam menjalankan usahataninya. Hal ini dapat terjadi karena semakin tua umur petani maka akan semakin matang dalam berpikir dan lebih adaptif terhadap inovasi teknologi dalam budidaya bawang merah. Petani yang relatif tua umumnya juga memiliki kapasitas pengelolaan yang lebih baik dan matang karena memiliki banyak pengalaman.

Distribusi tingkat efisiensi alokatif dan ekonomi usahatani bawang merah di Kabupaten Bantul disajikan pada Tabel 12 berikut ini.

Tingkat efisiensi alokatif yang dicapai oleh petani bawang merah di Kabupaten Bantul berkisar antara 0,381 hingga 1, dengan persentase terbanyak pada kelompok tingkat efisiensi $0,91-1$ sebesar $66,67 \%$. Petani dengan tingkat efisiensi alokatif antara 0,81-0,90 dan petani dengan tingkat efisiensi alokatif antara 0,61-0,70 menempati posisi terbanyak kedua dengan persentase masing-masing sebesar $10,00 \%$. Hal ini menunjukkan bahwa masih relatif banyak petani bawang merah yang berada dalam kondisi in-efisien secara alokatif. Rata-rata tingkat efisiensi alokatif yang dapat dicapai petani adalah sebesar 0,889. Angka ini menunjukkan bahwa masih ada ruang bagi petani bawang merah di Kabupaten Bantul untuk meningkatkan tingkat efisiensinya.

Efek kombinasi efisiensi teknis dan efisiensi alokatif petani bawang merah di Kabupaten Bantul memperlihatkan tingkat efisiensi ekonomi yang dapat dicapai oleh petani bawang merah di Kabupaten Bantul berkisar antara 0,379 hingga 1, dengan persentase terbanyak pada kelompok tingkat efisiensi $0,91-1$ sebesar $36,67 \%$. Sementara petani pada tingkat efisiensi antara 0,71-0,80 menempati jumlah terbanyak kedua dengan persentase sebesar 20,00\%. Ratarata tingkat efisiensi ekonomi adalah sebesar 0,798 sebagaimana ditunjukkan oleh Tabel 12. Hal ini menunjukkan apabila petani rata-rata dalam sampel dapat mencapai efisiensi ekonomi yang maksimum maka petani bawang merah di Kabupaten Bantul dapat merealisasikannya dengan penghematan biaya sebesar 20,2\% (1-[0,798/1]). Selain itu, apabila petani bawang merah yang paling inefisien dapat mencapai efisiensi ekonomi yang maksimum maka petani tersebut dapat merealisasikannya dengan penghematan biaya sebesar 62,1\% (1-[0,379/1]).

Hasil analisis menunjukkan bahwa tingkat efisiensi ekonomi usahatani bawang merah di Kabupaten Bantul masih dapat ditingkatkan. Satu hal yang perlu menjadi perhatian adalah terjadinya in-efisiensi teknis sebagai masalah yang lebih serius dibandingkan dengan in-efisiensi alokatif dalam upaya pencapaian tingkat efisiensi ekonomi yang lebih tinggi. Kondisi tersebut dikarenakan secara alokatif rata-rata petani dapat dikatakan cukup efisien (indeks efisiensi alokatif mendekati 0,9). Upaya pencapaian tingkat efisiensi ekonomi yang lebih tinggi harus dilakukan oleh petani dengan meningkatkan manajemen usahatani sekaligus memperbaiki tingkat alokasi input yang digunakan dengan memperhatikan harga input, yaitu dengan melakukan penambahan input yang kurang atau 
TABEL I2. DISTRIBUSI EFISIENSI ALOKATIF (EA) DAN EFIIIENSI EKONOMI (EE) USAHATANI BAWANG MERAH DI KABUPATEN BANTUL

\begin{tabular}{ccccc}
\hline \multirow{2}{*}{ Tingkat Efisiensi } & \multicolumn{2}{c}{ Efisiensi Alokatif } & \multicolumn{2}{c}{ Efisiensi Ekonomi } \\
\cline { 2 - 5 } & Jumlah Petani & Persentase & Jumlah Petani & Persentase \\
\hline$<0,5$ & 1 & 3,33 & 1 & 3,33 \\
$0,51-0,60$ & 1 & 3,33 & 4 & 13,33 \\
$0,61-0,70$ & 3 & 10,00 & 4 & 13,33 \\
$0,71-0,80$ & 2 & 6,67 & 6 & 20,00 \\
$0,81-0,90$ & 3 & 10,00 & 43,33 \\
$0,91-1,00$ & 20 & 66,67 & 11 & 36,67 \\
Jumlah & 30 & & 30 & \\
Rerata & 0,889 & & 0,798 & \\
Nilai Minimum & 0,381 & & 0,379 & 1 \\
Nilai Maksimum & 1 & & & \\
\hline
\end{tabular}

pengurangan input yang berlebihan sehingga dicapai tingkat biaya yang minimum.

\section{TABEL I3. INDEKS EFISIENSI TEKNIS, ALOKATIF, DAN EKONOMI USAHATANI BAWANG MERAH}

\begin{tabular}{lll}
\hline Uraian & & Indeks Efisiensi \\
\hline Efisiensi Teknis & (ET) & 0,802 \\
Efisiensi Alokatif & (EA) & 0,889 \\
\hline Efisiensi Ekonomi & (EE) & 0,798 \\
\hline
\end{tabular}

\section{KESIMPULAN}

Kegiatan usahatani bawang merah di Kabupaten Bantul adalah usahatani yang menguntungkan dengan pendapatan sebesar Rp20.903.711/ha. Tingkat risiko yang dihadapi petani cukup tinggi, yaitu sebesar 0,727 atau $72,7 \%$. Artinya untuk setiap satu rupiah dari pendapatan yang diterima oleh petani, maka risiko yang dihadapi adalah sebesar $0,727 \mathrm{ru}-$ piah. Selain itu, petani bawang merah harus berani menanggung kerugian sebesar Rp9.480.916 pada setiap proses produksi. Rata-rata tingkat efisiensi teknis, alokatif, dan ekonomi usahatani bawang merah di Kabupaten Bantul masing-masing adalah 0,802; 0,889; dan 0,929. Hasil ini menunjukkan bahwa tingkat efisiensi usahatani bawang merah di Kabupaten Bantul masih dapat ditingkatkan.

Peningkatan produksi dan pendapatan usahatani bawang merah di Kabupaten Bantul dapat dilakukan dengan menambah luas lahan garapan dan juga dengan mengalokasikan faktor-faktor produksi secara optimal. Upaya pencapaian tingkat efisiensi ekonomi yang lebih tinggi dapat dilakukan dengan meningkatkan manajemen usahatani sekaligus memperbaiki tingkat alokasi input yang digunakan dengan memperhatikan harga input sehingga dicapai tingkat biaya yang minimum.

\section{DAFTAR PUSTAKA}

Badan Penelitian dan Pengembangan Pertanian. 2005. Prospek dan Arah Pengembangan Agribisnis Bawang Merah. Balitbang-Depertemen Pertanian, Jakarta.

Bank Indonesia. 2013. Pola Pembiayaan Usaha Kecil Menengah Usaha Budidaya Bawang Merah. BI, Jakarta.

Coelli, T. J. 1996. A Guide to Frontier Version 4.1: Program for Stochastic Frontier Production and Cost Function Esttimation. CEPA Working Paper 07/96. University of New England.

Coelli, T. J., Rao, D. S. P., O'Donnel, C. J., \& Battese, G. E. 1998. An Introduction to Efficiency and Productivity Analysis. Springer, New York.

Fadwiwati, A. Y., Hartoyo, S., Kuncoro, S. U., \& Rusastra, I. W. 2014. Analisis efisiensi teknis, efisiensi alokatif, dan efisiensi ekonomi usahatan jagung berdasarkan varietas di Provinsi Gorontalo. Jurnal Agro Ekonomi 32 (1): 1-12

Mubyarto. 1982. Pengantar Ekonomi Pertanian. LP3ES, Jakarta.

Ogundari, K. \& Ojo, S. O. 2007. An examination of technical economic and an allocative efficiency of small farm: the case study of cassava farmers in Osun State of Nigeria. Bulgarian Jurnal of Agricultural Science 13: 185-195.

Saptana, Daryarto, A., Daryanto, H. K., \& Kuntjoro. 2010. Strategi manajemen resiko petani cabai merah pada lahan sawah dataran rendah di Jawa Tengah. Jurnal Manajemen \& Agribisnis 7 (2).

Sukiyono, K. 2005. Faktor penentu tingkat efisiensi teknik usahatani cabai merah di Kecamatan Selupu Rejang Kabupaten Rejang Lebong. Jurnal Agro Ekonomi 23(2): 176-190. 